\title{
PENGARUH KONFLIK DAN STRES TERHADAP KINERJA KARYAWAN KAP, DIINTERVENING OLEH BUDAYA ORGANISASI
}

\author{
Erika Sandora dan I Gede Adiputra \\ Program Studi Manajemen Fakultas Ekonomi, Universitas Tarumanagara, Jakarta \\ erikasandora68@gmail.com
}

\begin{abstract}
Employee performance in a company does not always run smoothly, sometimes even employee performance can decrease dramatically. This is because there are several factors that cause a decrease in employee performance, one of which is conflict and stress. The purpose of this study was to determine and analyze the effect of conflict and stress on employee performance that is intervene by the organizational culture at Kantor Akuntan Publik. The data were obtained by distributing questionnaires to 50 employees of Kantor Akuntan Publik Drs. Tommy Santoso. The analysis method used in this research is Structural Equation Modeling (SEM). This study uses a measurement model analysis of validity and reliability tests. Based on the results of path analysis, it shows that conflict and stress have a negative and significant effect on the employee performance, organizational culture has a positive and significant effect on employee performance, organizational culture can significantly intervene the relations between conflict and employee performance and organizational culture can significantly intervene the relations between stress and employee performance at Kantor Akuntan Publik.
\end{abstract}

Keywords: Conflict, Stress, Performance, Organizational Culture.

Abstrak: Kinerja karyawan di dalam suatu perusahaan tidak selalu berjalan dengan mulus, bahkan terkadang kinerja karyawan dapat menurun drastis. Hal tersebut dikarenakan terdapat beberapa faktor yang menyebabkan penurunan kinerja karyawan, salah satunya yaitu konflik dan stres. Tujuan dari penelitian ini adalah untuk mengetahui dan menganalisis pengaruh konflik dan stres terhadap kinerja karyawan yang diintervening oleh budaya organisasi pada Kantor Akuntan Publik. Data diperoleh dengan menyebarkan kuisioner kepada 50 karyawan Kantor Akuntan Publik Drs. Tommy Santoso. Metode analisis yang digunakan dalam penelitian ini adalah Structural equation model (SEM). Penelitian ini menggunakan analisis model pengukuran uji validitas dan uji reliabilitas. Berdasarkan hasil analisis jalur (path analysis) menunjukkan bahwa konflik dan stres berpengaruh negatif dan signifikan terhadap kinerja karyawan, budaya organisasi berpengaruh positif dan signifikan terhadap kinerja karyawan, budaya organisasi dapat mengintervening hubungan antara konflik dan kinerja karyawan secara signifikan dan budaya organisasi dapat mengintervening hubungan antara stres dan kinerja karyawan secara signifikan pada Kantor Akuntan Publik.

Kata Kunci: Konflik, Stres, Kinerja, Budaya Organisasi.

\section{PENDAHULUAN}

Manajemen sumber daya manusia merupakan ilmu yang mempelajari bagaimana menciptakan suatu pekerjaan, membentuk kelompok kerja, memberdayakan karyawan, mengidentifikasi suatu pendekatan, memberikan pelatihan/pengembangan bagi para karyawan yang mempunyai kemampuan, dan memberikan karyawan imbalan atas hasil kerja kerasnya. Manajemen sumber daya manusia berfokus mempelajari tentang unsur-unsur sumber daya 
manusia. Selain itu manajemen sumber daya manusia juga mempelajari tentang hal-hal yang berkaitan dengan ketenagakerjaan, baik itu secara berkelompok maupun individu. Manajemen sumber daya manusia berpengaruh secara langsung dengan semua keputusan dan praktik manajemen. Dalam semua aktivitas, organisasi manusia merupakan sumber daya yang strategis, maka dari itu perlu dirumuskan dan direncanakan strategi yang relevan dengan tujuan yang ditetapkan. Ciri-ciri sumber daya manusia yang strategis adalah perencanaan SDM yang benar dan terorganisir dengan baik. Suatu perusahaan atau organisasi menuntut manajemen sumber daya manusia untuk membuat inovasi baru, yaitu bagaimana cara mempertahankan produktifitas pegawai yang tinggi dan mengembangkan potensi sumber daya manusia agar memberikan kontribusi penuh demi mencapai tujuan perusahaan.

Peran karyawan sebagai anggota sangatlah penting dalam menjalankan tugas dan fungsi perusahaan, hal tersebut dapat diukur dari peran karyawan, kinerja dan kompetensi. Dengan Persaingan yang semakin ketat, diharapkan karyawan dapat meningkatkan kinerjanya agar sasaran perusahaan dapat tercapai. Dalam hal ini, kinerja merujuk pada kemampuan karyawan dalam memenuhi tujuan yang sudah ditetapkan dan tingkat keberhasilan untuk melaksanakan tugas yang diberikan.

Konflik yaitu persaingan tidak sehat yang didasarkan oleh sikap emosional dan ambisi untuk mendapatkan kemenangan. Jika para pelaku konflik tidak dapat menyelesaikan permasalahan dengan baik, maka akan timbul perkelahian, ketegangan, frustasi dan konfrontasi. Konflik kerap muncul dalam suatu organisasi sehingga kadang menyebabkan suatu perpecahan antar kelompok maupun individu. Dalam penanganannya, konflik harus diselesaikan dengan tuntas agar tidak berdampak pada pelaku konflik lainnya atau korban dari konflik tersebut. Langkah awal yang harus diketahui yaitu akar permasalahan yang terjadi antar kedua belah pihak.

Stres selalu dihubungkan dengan karakteristik atau psikologis seseorang, yang artinya setiap wujud tindakan eksternal, peristiwa atau situasi yang menempatkan fisik atau psikologis khusus pada individu akan menimbulkan konsekuensi. Karyawan yang mengalami gejala negatif tersebut pada akhirnya akan berpengaruh pada prestasi kerja sehingga karyawan mengalami penurunan motivasi kerja. Stres dalam suatu organisasi biasanya disebabkan karena struktur organisasi yang dibentuk berdasarkan desain organisasi yang telah ada, seperti konflik antar sesama karyawan, lingkungan kerja yang tidak mendukung, diferensiasi dan sentralisasi.

Budaya Organisasi adalah pedoman utama bagi suatu organisasi untuk bergerak dalam memecahkan suatu masalah, menyatukan anggota dalam suatu organisasi dan mengubah karyawan agar dapat beradaptasi di lingkungan baru. Budaya organisasi memfokuskan diri pada pembelajaran tentang norma dan nilai yang tercermin pada perilaku atau tindakan organisasi itu sendiri. Faktanya bahwa norma dan nilai-nilai tentang cara berperilaku diciptakan oleh organisasi itu sendiri, maka tatkala karyawan itu sendirilah yang harus menjalankannya dengan patuh.

Berdasarkan data di lapangan, dapat diketahui tujuan dari penelitian ini. Yaitu untuk mengetahui pengaruh konflik terhadap kinerja karyawan KAP, untuk mengetahui pengaruh stres terhadap kinerja karyawan KAP, untuk mengetahui pengaruh budaya organisasi terhadap kinerja karyawan KAP, untuk mengetahui apakah budaya organisasi dapat memediasi hubungan antara konflik dan kinerja karyawan KAP dan untuk mengetahui apakah budaya organisasi dapat memediasi hubungan antara stres dan kinerja karyawan KAP.

\section{KAJIAN TEORI}

\section{Kinerja}

Kinerja atau performance yang mengacu pada hasil pekerjaan yang dilakukan oleh seseorang dengan proses manajemen atau seluruh organisasi. Hasil usaha seorang karyawan 
ditunjukkan di tempat kerja dan dapat diukur/dibandingkan dengan standar yang telah ditentukan (Sedarmayanti, 2011). Kinerja dapat diketahui dan diukur jika individu atau sekelompok karyawan telah mempuanyai kriteria atau standar keberhasilan tolak ukur yang ditetapkan oleh organisasi. Oleh karena itu, jika tanpa tujuan dan target yang ditetapkan dalam pengukuran, maka kinerja pada seseorang atau kinerja organisasi tidak mungkin dapat diketahui bila tidak ada tolok ukur keberhasilannya.

\section{Konflik}

Konflik merupakan warisan kehidupan sosial yang boleh berlaku dalam berbagai keadaan akibat daripada berbangkitnya keadaan ketidaksetujuan, kontroversi, dan pertentangan diantara dua pihak atau lebih secara berkesinambungan (Newstorm dan Davis, 2000). Biasanya konflik muncul akibat tidak adanya rasa toleransi dan saling mengerti kebutuhan masingmasing individu. konflik terdapat adanya dua pihak atau lebih, masing-masing pihak memobilisasi energi atau sumber daya untuk mencapai suatu tujuan tertentu, sebuah objek atau situasi tertentu yang dikehendaki, dan masing-masing pihak beranggapan bahwa pihak lain merupakan sebuah kendala atau ancaman baginya dalam hal mencapai tujuan.

\section{Stres}

Stres adalah suatu kondisi yang disebabkan oleh ketidaksesuaian antara situasi ideal dengan keadaan biologis, psikologis atau sosial individu (Sarafino, 2006). Stres bersifat sangat individual, jika tidak ada keseimbangan antara ketahanan psikologis individu dengan beban yang dipikulnya, maka pada dasarnya dapat bersifat merusak (David, Hager dan Linda C, 1999). Akan tetapi, menghadapi stresor (stressor) tidak selalu menimbulkan hambatan psikologis atau fisik. Seseorang akan terganggu atau tidak tergantung pada persepsi individu tentang peristiwa yang dialami. Faktor kunci dari stres adalah persepsi dan penilaian seseorang terhadap situasi, dan kemampuannya untuk menghadapi atau memanfaatkan situasi yang sedang terjadi.

\section{Budaya Organisasi}

Budaya organisasi adalah norma dan nilai yang menjadi pedoman berperilaku anggota organisasi (Luthans,1998). Dengan memperhatikan pedoman budaya organisasi, setiap anggota organisasi akan bertindak sesuai dengan budaya yang sedang berkembang pada saat itu agar dapat diterima oleh lingkungan sekitarnya. Budaya organisasi merupakan model keyakinan dan nilai-nilai organisasi yang dipahami, ditanamkan, dan dipraktikkan oleh organisasi tersebut, oleh karena itu model ini mempunyai arti tersendiri dan menjadi dasar dari aturan berperilaku dalam suatu organisasi (Andreas Lako, 2004).

\section{Pengembangan Hipotesis \& Kerangka Pemikiran Pengaruh Konflik terhadap Kinerja Karyawan}

Konflik merupakan suatu pertentangan yang terjadi antara apa yang diharapkan oleh seseorang terhadap dirinya, orang lain, organisasi dengan kenyatan apa yang diharapkannya (Anwar Prabu Mangkunegara, 2005). Semakin tinggi frekuensi konflik maka semakin rendah kinerja karyawan, terutama pada konflik yang uumnya terjadi pada individu atau disfungsional. Dari hasil penelitian ini menunjukkan bahwa perusahaan harus mampu meningkatkan komunikasi antar karyawan dan antara pimpinan dengan bawahan untuk menghindari adanya konflik. Hasil penelitian ini searah dengan penelitian Siti Krisnawati dan Yuyun Tri Lestari (2014) yang menyatakan bahwa konflik berpengaruh secara negatif dan signifikan terhadap kinerja karyawan.

H1: Konflik berpengaruh signifikan terhadap kinerja karyawan Kantor Akuntan Publik. 


\section{Pengaruh Stres terhadap Kinerja Karyawan}

Stres adalah suatu kondisi ketegangan yang menciptakan adanya ketidakseimbangan fisik dan psikis, yang mempengaruhi emosi, proses berpikir dan kondisi seorang karyawan. Seperti : rasa takut, cemas, rasa bersalah, marah, sedih, putus asa dan bosan yang dihadapinya dalam lingkungan kerja. (Veithzal Rivai, 2004). Menurut hasil penelitian yang telah dilakukan, jika stres meningkat maka kinerja karyawan akan menurun. Begitu pula jika stres rendah maka kinerja karyawan juga akan meningkat. Dalam beberapa tahapan, stres akan meningkatkan kinerja karyawan, namun semakin tinggi tingkat stres akan berdampak secara menyeluruh terhadap penurunan kinerja karyawan di dalam suatu organisasi/perusahaan. Hasil penelitian ini didukung oleh Wilian (2016), yang berpendapat bahwa stres berpengaruh secara negatif dan signifikan terhadap kinerja karyawan.

\section{H2: Stres berpengaruh signifikan terhadap kinerja karyawan Kantor Akuntan Publik.}

\section{Pengaruh Budaya Organisasi terhadap Kinerja Karyawan}

Budaya organisasi merupakan gabungan kompleks dari asumsi, tingkah laku, cerita, mitos, metafora dan berbagai ide lain yang menjadi satu untuk menentukan apa arti menjadi anggota masyarakat tertentu (Stoner et al., 1996). Semakin baik suatu budaya organisasi maka kinerja karyawan akan meningkat. Hasil penelitian ini searah dengan penelitian Steven Christian Pangandaheng, Ivonne S.Saerang dan Sjendry S.R. Loindong (2008), yang menyatakan bahwa budaya organisasi berpengaruh secara positif dan signifikan terhadap kinerja karyawan.

\section{H3: Budaya organisasi berpengaruh signifikan terhadap Kinerja Karyawan Kantor} Akuntan Publik Drs. Tommy Santoso

\section{Pengaruh Konflik dan Kinerja Karyawan yang diintervening oleh Budaya Organisasi}

Apabila dalam kinerja karyawan menggalami penurunan berarti telah terjadi peningkatan konflik kerja yang dialami oleh karyawan. Begitu pula sebaliknya, apabila terjadi penurunan terhadap konflik kerja maka akan berpengaruh pada peningkatan pada kinerja karyawan Hasil penelitian ini searah dengan penelitian Ferdian Fatikhin, Djamhur Hamid dan M. Djudi Mukzam, yang menyatakan bahwa konflik dan kinerja karyawan dimediasi oleh budaya organisasi secara negatif dan signifikan.

H4A: Budaya Organisasi dapat mengintervening hubungan antara Konflik dan Kinerja Karyawan secara signifikan.

\section{Pengaruh Stres dan Kinerja Karyawan yang diintervening oleh Budaya Organisasi}

Stres disebabkan oleh berbagai faktor yang membuat karyawan merasa tidak nyaman. Faktor penyebab stres adalah faktor pekerjaan, faktor non kerja dan faktor kepribadian (Triatna, 2015). Diketahui bahwa hasil dari penelitian uji intervening menunjukkan hasil yang signifikan berpengaruh negatif, yang artinya bila tingkat stres dikurangi maka kinerja akan meningkat, begitupun sebaliknya semakin tinggi tingkat stres maka kinerja karyawan mengalami penurunan. Hasil penelitian ini searah dengan penelitian Cristine Julvia yang menyatakan bahwa stres dan kinerja karyawan dimediasi oleh budaya organisasi secara negatif dan signifikan. 


\section{H4B: Budaya Organisasi dapat mengintervening hubungan antara Stres dan Kinerja Karyawan secara signifikan}

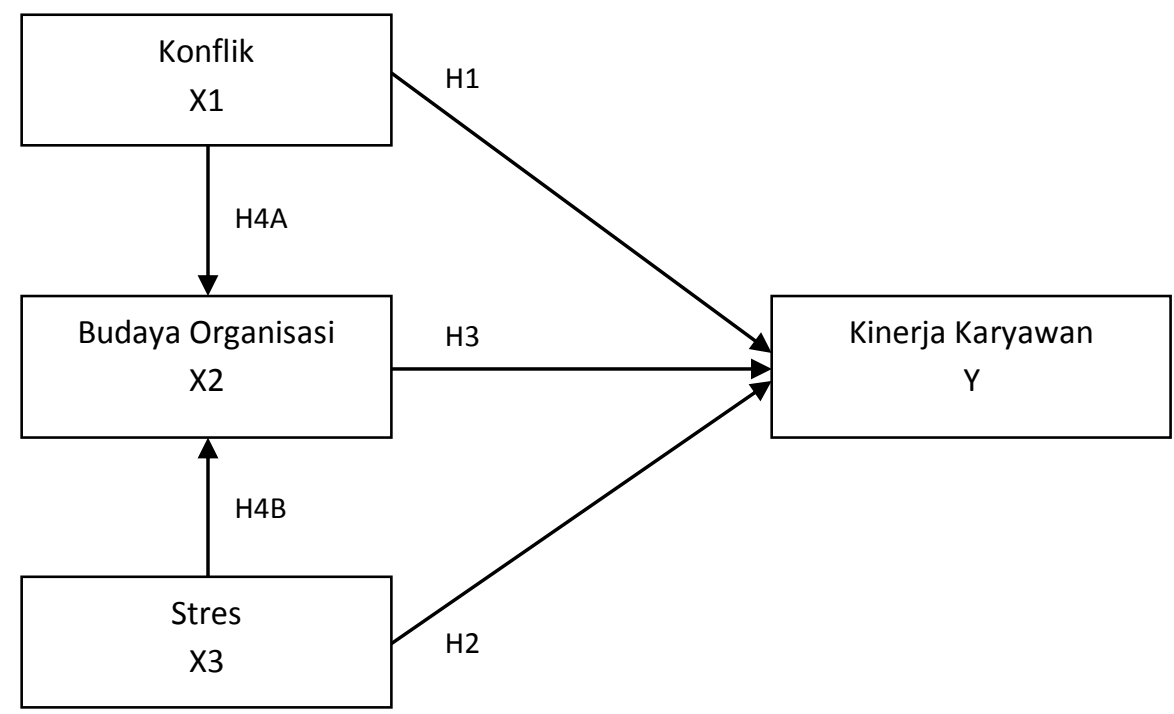

Gambar 1. Kerangka Pemikiran

\section{METODOLOGI}

Desain penelitian yang akan digunakan untuk penelitian ini yaitu kausal. Desain penelitian kausal umumnya merupakan penelitian yang digunakan untuk mengetahui dan menggambarkan adanya hubungan sebab dan akibat antara variabel dependen dan variabel independen serta variabel mediasi. Sedangkan pendekatan yang akan digunakan dalam penelitian ini yaitu kuantitatif dengan menetapkan Karyawan Kantor Akuntan Publik Drs. Tommy Santoso sebagai populasinya. Teknik pemilihan sampel dalam penelitian ini yaitu nonprobability sampling dengan purposive sampling. Kuisioner dibagikan kepada 50 orang responden di Jakarta Pusat dengan kriteria karyawan yang bekerja di Kantor Akuntan Publik Drs. Tommy sebagai subjek penelitian. Objek penelitian ini adalah variabel-variabel yang diteliti yaitu, konflik dan stres sebagai variabel independen, kinerja karyawan sebagai variabel dependen serta budaya organisasi sebagai variabel intervening. Instrumen penelitian yang digunakan dalam penelitian ini yaitu kuesioner dan skala likert yang digunakan untuk mengukur permasalahan yang ingin diketahui dengan memberikan pertanyaan kepada responden serta pengukuran yang dilakukan dengan memberikan jawaban dari sangat setuju hingga tidak setuju

Analisis data yang akan digunakan pada penelitian ini menggunakan software partial least square (PLS) dan metode analisis data menggunakan Structural equation model (SEM) yang terdiri dari 2 langkah yaitu model pengukuran (outer model) dan model struktural (inner model). Outer model terbagi menjadi dua yaitu, uji validitas dan reliabilitas. Sedangkan inner model terbagi menjadi Koefisien Determinasi (R2), Effect size (f2), Predictive Relevance (Q2), Path Coefficient dan Uji Goodness of Fit (GoF).

\section{HASIL ANALISIS DATA}

Uji validitas konvergen dapat dilihat melalui nilai Average Variance Extracted (AVE). AVE menggambarkan rata-rata varians atau diskriminan yang diekstrak pada setiap indikator, 
sehingga kemampuan masing-masing item dalam membagi pengukuran dengan yang lain dapat diketahui. Nilai AVE sama dengan atau di atas 0,5 menunjukkan adanya convergent yang baik atau dikatakan valid.

Tabel 1

Hasil Uji Average Variance Extracted (AVE)

\begin{tabular}{|c|c|}
\hline Variabel & Average Variance Extracted $(\boldsymbol{A V E})$ \\
\hline Budaya Organisasi & 0.810 \\
\hline Kinerja Karyawan & 0.777 \\
\hline Konflik & 0.937 \\
\hline Stres & 0.895 \\
\hline
\end{tabular}

Berdasarkan tabel 1, menunjukkan bahwa Budaya Organisasi, Kinerja Karyawan, Konflik dan Stres memiliki nilai AVE masing-masing sebesar 0.810, 0.777, 0.937 dan 0.895. Nilai AVE yang ditunjukkan pada tabel diatas telah melebihi kriteria nilai AVE, yaitu >0,5. Maka dapat disimpulkan bahwa dari keempat variabel tersebut dinyatakan valid.

Uji reliabilitas dilakukan untuk menguji konsistensi dan Stabilitas nilai suatu data. Pengujian dapat dilakukan dengan melihat nilai Composite Reliability dan Cronbach Alpha dari variabel-variabel yang terdapat dalam penelitian. Reliabilitas terpenuhi apabila nilai pada Cronbach's Alpha > 0,70 dan nilai Composite Reliability lebih besar atau sama dengan 0,7.

Tabel 2

Hasil Uji Reliabilitas (Cronbach's Alpha)

\begin{tabular}{|c|c|c|}
\hline Variabel & Cronbach's Alpha & Composite Reliability \\
\hline Budaya Organisasi & 0.921 & 0.945 \\
\hline Kinerja Karyawan & 0.904 & 0.933 \\
\hline Konflik & 0.978 & 0.984 \\
\hline Stres & 0.961 & 0.972 \\
\hline
\end{tabular}

Dari tabel 2, diketahui bahwa nilai Cronbach's Alpha dari setiap variabel lebih besar dari 0,7 dan nilai Composite Reliability untuk seluruh variabel di atas 0,7. Oleh karena itu, seluruh variabel dinyatakan reliabel.

Koefisien Determinasi (R2) menunjukkan besarnya kontribusi dari variabel independen (Stres dan Konflik) terhadap variabel dependen (Kinerja Karyawan) dan variabel itervening (Budaya Organisasi). Semakin besar nilai R-Square (R2) artinya semakin kuat dan baik suatu model prediksi yang dipengaruhi dari model penelitian.

Tabel 3

Hasil Uji $R$-square $\left(\boldsymbol{R}^{2}\right)$

\begin{tabular}{|c|c|}
\hline Variabel & $\boldsymbol{R}$-Square $\left(\boldsymbol{R}^{2}\right)$ \\
\hline Budaya Organisasi & 0.821 \\
\hline Kinerja Karyawan & 0.958 \\
\hline
\end{tabular}

Tabel 3, menunjukan bahwa nilai koefisien determinasi $\left(\mathrm{R}^{2}\right)$ sebesar 0.821 yang berarti sebesar $82,1 \%$ dari variabel Budaya Organisasi mengalami perubahan pada variabel 
independen pada penelitian ini (Stres dan Konflik) sedangkan sisanya sebesar 17,9\% dapat dijelaskan oleh variabel lain di luar penelitian ini.

Sedangkan nilai koefisien determinasi $\left(\mathrm{R}^{2}\right)$ dari variabel kinerja karyawan sebesar 0.958 yang berarti sebesar 95,8\% dari variabel Kinerja Karyawan mengalami perubahan pada variabel independen pada penelitian ini (Stres dan Konflik), sisanya sebesar 4,2\% dapat dijelaskan oleh variabel lain di luar penelitian ini.

Effect Size $\left(\mathrm{F}^{2}\right)$ dilakukan untuk mengetahui bagaimana variabel independen sebagai prediktor memiliki efek pada model penelitian ini. Pengujian Effect Size juga biasanya digunakan untuk melihat kebaikan model yang terbentuk. Nilai Effect size atau $\mathrm{F}^{2}$ diberi nilai 0.02 jika dianggap kecil, 0.15 dianggap sedang dan 0.35 dianggap besar. Sedangkan jika dibawah 0.02, dapat diabaikan atau dianggap tidak memiliki efek.

Tabel 4

Hasil Uji Effect Size $\left(F^{2}\right)$

\begin{tabular}{|c|c|c|}
\hline Variabel & Budaya Organisasi & Kinerja Karyawan \\
\hline Budaya Organisasi & & 1.395 \\
\hline Kinerja Karyawan & & 0.286 \\
\hline Konflik & 0.144 & 0.148 \\
\hline Stres & 0.430 & \\
\hline
\end{tabular}

Berdasarkan tabel 4 dapat disimpulkan bahwa variabel budaya organisasi mempunyai nilai effect size sebesar 1.395 yang berarti bahwa budaya organisasi memiliki efek yang tergolong besar terhadap kinerja karyawan, variabel konflik mempunyai nilai effect size sebesar 0.286 yang berarti bahwa konflik memiliki efek yang tergolong sedang terhadap kinerja karyawan dan variabel stres mempunyai nilai effect size sebesar 0.148 yang berarti bahwa stres memiliki efek yang tergolong sedang terhadap kinerja karyawan.

Selanjutnya, dapat disimpulkan bahwa variabel konflik mempunyai nilai effect size sebesar 0.144 yang berarti bahwa konflik memiliki efek yang tergolong kecil terhadap kinerja karyawan dan variabel stres mempunyai nilai effect size sebesar 0.430 yang berarti bahwa stres memiliki efek yang tergolong besar terhadap kinerja karyawan.

Predictive Relevance (Q2) dilakukan untuk mengetahui apakah konstruk dari setiap variabel pada penelitian dapat digunakan untuk mengukur model penelitian. Syarat pengujian Q Square predictive relevance adalah nilai Q Square > 0 .

Tabel 5

Hasil Uji Predictive Relevance $\left(Q^{2)}\right.$

\begin{tabular}{|c|c|}
\hline Variabel & Predictive Relevance $\left(\boldsymbol{Q}^{2)}\right.$ \\
\hline Kinerja Karyawan & 0.992 \\
\hline
\end{tabular}

Tabel 5 menunjukkan bahwa nilai Q2 sebesar 0.992 (Q2 > 0), sehingga kesimpulan yang dapat diperoleh adalah konstruk dari setiap variabel yang terdapat dalam penelitian ini, layak atau dapat digunakan untuk mengukur model penelitian.

Tujuan dari dilakukannya uji goodness of fit adalah untuk mengetahui evaluasi model pengukuran struktural serta menyediakan pengukuran sederhana untuk keseluruhan dari prediksi model. Atau digunakan untuk memvalidasi gabungan antara model pengukuran (outer model) dan model struktural (inner model). Jika nilainya 0,1 dinyatakan kecil, nilainya 0,25 diyatakan sedang dan nilainya 0.36 dinyatakan besar. Berikut perhitungan Goodness of Fit yang dilakukan secara manual dan diuraikan sebagai berikut ini. 
Tabel 6

\begin{tabular}{|c|c|c|}
\multicolumn{3}{|c}{ Tabel $\left(\overline{A V E} \bar{x}^{R^{2}}\right)$} \\
\hline Variabel & AVE & $\mathbf{R}^{\mathbf{2}}$ \\
\hline $\begin{array}{c}\text { Budaya } \\
\text { Organisasi }\end{array}$ & 0.810 & 0.821 \\
\hline $\begin{array}{c}\text { Kinerja } \\
\text { Karyawan }\end{array}$ & 0.777 & 0.958 \\
\hline Konflik & 0.937 & \\
\hline Stres & 0.895 & $\mathbf{0 . 8 9 0}$ \\
\hline $\begin{array}{c}\text { Nilai rata }- \\
\text { rata }\end{array}$ & $\mathbf{0 . 8 5 5}$ & \\
\hline
\end{tabular}

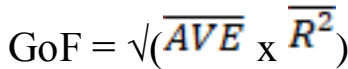

$\mathrm{GoF}=\sqrt{ }(0,855 \times 0,890)$

$\mathrm{GoF}=0,872$

Berdasarkan hasil perhitungan nilai Goodness of Fit tersebut, maka dapat disimpulkan bahwa model penelitian yang digunakan dalam penelitian ini memiliki goodness of fit yang tergolong besar yaitu sebesar 0,872 .

Path coefficients dilakukan dengan tujuan untuk mengetahui keterkaitan antar satu variabel dengan variabel lainnya. Pengujian hipotesis menggunakan teknik bootstrapping yang bertujuan untuk mengetahui efek tidak langsung (indirect effect) dan efek langsung (direct effect) serta tingkat signifikansinya dari variabel intervening budaya organisasi. Hasil dari pengujian tersebut dapat dilihat pada tabel 7 sebagai berikut.

Tabel 7

Hasil Uji Path Coefficient

\begin{tabular}{|c|c|c|c|}
\hline Variabel & $\begin{array}{c}\text { Original } \\
\text { Sample (O) }\end{array}$ & T-Statistics & P-Values \\
\hline $\begin{array}{c}\text { Budaya } \\
\text { Organisasi -> Kinerja } \\
\text { Karyawan }\end{array}$ & 0.569 & 8.108 & 0.000 \\
\hline $\begin{array}{c}\text { Konflik -> } \\
\text { Budaya Organisasi }\end{array}$ & -0.342 & 2.357 & 0.019 \\
\hline $\begin{array}{c}\text { Konflik -> } \\
\text { Kinerja Karyawan }\end{array}$ & -0.248 & 3.323 & 0.001 \\
\hline
\end{tabular}

Dari persamaan yang sudah terbentuk tersebut, dapat diketahui bahwa nilai path coefficients dari variabel terhadap kinerja karyawan memiliki arah positif yaitu sebesar 0.569 , nilai path coefficients dari variabel konflik terhadap budaya organisasi memiliki arah negatif yaitu sebesar -0.342 , nilai path coefficients dari variabel konflik terhadap kinerja karyawan memiliki arah negatif yaitu sebesar -0.248 , nilai path coefficients dari variabel stres terhadap budaya organisasi memiliki arah negatif yaitu sebesar -0.590 dan nilai path coefficients dari variabel stres terhadap kinerja karyawan memiliki arah negatif yaitu sebesar -0.199 .

Budaya Organisasi merupakan variabel perantara atau variabel intervening dalam penelitian ini. Tujuan dari hasil uji ini adalah menguji pengaruh variabel intervening didalam penelitian ini menggunakan metode path (Path Analysis). Hubungan kausalitas antar variabel dibentuk berdasarkan landasan teori dan dilakukan oleh dengan analisis jalur untuk 
menemukan pola hubungan antara tiga atau lebih dari variabel lainnya. Berdasarkan Tabel 8 di bawah ini menunjukkan bahwa hasil dari uji intervening indirect effect dapat dijelaskan sebagai berikut:

Tabel 8

Hasil Uji Indirect Effect

\begin{tabular}{|c|c|}
\hline Variabel & $\begin{array}{r}\text { P } \\
\text { Values }\end{array}$ \\
\hline $\begin{array}{c}\text { Konflik -> Budaya Organisasi -> Kinerja } \\
\text { Karyawan }\end{array}$ & 0.024 \\
\hline Stres -> Budaya Organisasi -> Kinerja Karyawan & 0.000 \\
\hline
\end{tabular}

Dapat diketahui bahwa nilai P-values dari variabel konflik terhadap kinerja karyawan melalui budaya organisasi sebagai variabel intervening sebesar 0.024 (nilai p-values lebih kecil dari 0,05). Berdasarkan hasil tersebut maka hasil uji intervening tidak ditolak dan dapat disimpulkan bahwa budaya organisasi dapat mengintervening hubungan antara konflik dan kinerja karyawan secara signifikan.

Dapat diketahui bahwa nilai P-values dari variabel stres terhadap kinerja karyawan melalui budaya organisasi sebagai variabel intervening sebesar 0.000 (nilai p-values lebih kecil dari 0,05). Berdasarkan hasil tersebut maka hasil uji intervening tidak ditolak dan dapat disimpulkan bahwa budaya organisasi dapat mengintervening hubungan antara konflik dan kinerja karyawan secara signifikan.

\section{DISKUSI}

Berdasarkan hasil pengujian ini menunjukkan bahwa konflik memiliki pengaruh yang signifikan terhadap kinerja karyawan Kantor Akuntan Publik Drs. Tommy Santoso, hal ini disebabkan karena banyaknya perbedaan dalam arah komunikasi, persepsi, tujuan dan saling ketergantungan dalam pekerjaan. Konflik adalah kondisi yang ditimbulkan oleh adanya kekuatan yang saling bertentangan. Kekuatan-kekuatan ini bersumber pada keinginan manusia.

Berdasarkan hasil pengujian ini menunjukkan bahwa stres memiliki pengaruh yang signifikan terhadap kinerja karyawan Kantor Akuntan Publik Drs. Tommy Santoso, hal ini disebabkan karena faktor perbedaan nilai terhadap pegawai, beban kerja, keadaan kerja yang tidak sehat, tekanan/desakan waktu dan keadaan kerja yang tidak sehat. Stres mengacu pada respon dalam penyesuaian diri oleh individu, karena perilaku lingkungan, situasi atau peristiwa memiliki terlalu banyak tuntutan psikologis dan fisik pada orang, perbedaan individu dan proses psikologis akan mempengaruhi stres.

Berdasarkan hasil pengujian ini menunjukkan bahwa budaya organisasi memiliki pengaruh yang signifikan terhadap kinerja karyawan Kantor Akuntan Publik Drs. Tommy Santoso, hal ini disebabkan karena adanya profesionalisme, jarak manajemen, percaya pada rekan kerja dan integrasi. Budaya organisasi merupakan model keyakinan dan nilai-nilai organisasi yang dipahami, ditanamkan, dan dipraktikkan oleh organisasi tersebut, oleh karena itu model ini mempunyai arti tersendiri dan menjadi dasar dari aturan berperilaku dalam suatu organisasi.

Berdasarkan hasil pengujian ini menunjukkan bahwa konflik memilki pengaruh signifikan terhadap kinerja karyawan Kantor Akuntan Publik Drs. Tommy Santoso melalui budaya organisasi sebagai variabel intervening, apabila didalam kinerja karyawan menggalami penurunan berarti telah terjadi peningkatan konflik kerja yang dialami oleh karyawan. Begitu 
pula sebaliknya, apabila terjadi penurunan terhadap konflik kerja maka akan berpengaruh pada peningkatan pada kinerja karyawan.

Berdasarkan hasil pengujian ini menunjukkan bahwa stres memilki pengaruh signifikan terhadap kinerja karyawan Kantor Akuntan Publik Drs. Tommy Santoso melalui budaya organisasi sebagai variabel intervening. Faktor penyebab stres adalah faktor pekerjaan, faktor non kerja dan faktor kepribadian, yang artinya bila tingkat stres dikurangi maka kinerja akan meningkat, begitupun sebaliknya semakin tinggi tingkat stres maka kinerja karyawan mengalami penurunan.

\section{PENUTUP}

Berdasarkan hasil penelitian dan hasil pembahasan dari penelitian yang dilakukan, sehingga dapat disimpulkan bahwa terdapat pengaruh konflik terhadap kinerja karyawan, terdapat pengaruh stres terhadap kinerja karyawan, terdapat pengaruh budaya organisasi terhadap kinerja karyawan, budaya organisasi dapat mengintervening hubungan antara konflik dan kinerja karyawan dan budaya organisasi dapat mengintervening hubungan antara stres dan kinerja karyawan.

Penelitian ini memiliki beberapa keterbatasan dalam meneliti yaitu penelitian ini dibatasi dengan penggunaan dua variabel bebas dan satu variabel intervening untuk menjelaskan kinerja karyawan yaitu konflik dan stres dengan budaya organisasi sebagai variabel intervening dan dalam penelitian ini, jumlah responden masih terbatas karena adanya keterbatasan waktu. Sedangkan saran dari hasil penelitian ini yaitu, disarankan untuk menambah jumlah responden agar hasil penelitian yang diperoleh dapat lebih merepresentasikan populasi dan pengetahuan serta informasi tentang orientasi perusahaan yang didapatkan lebih berguna untuk meningkatkan kinerja karyawan dan disarankan untuk menggunakan variabel independen lainnya yang diduga dapat menjelaskan kinerja karyawan antara lain seperti motivasi kerja, kepuasan kerja dan komitmen organisasi. Sehingga dapat memberikan informasi yang lebih akurat dalam mengambil keputusan untuk meningkatkan kinerja karyawan.

\section{DAFTAR PUSTAKA}

Kurniawan, B.R., Sularso, R.A., \& Titisari, P. (2018). The effect of work conflict and job stress on employees performance with organizational commitment as intervening variable. Jurnal Manajemen dan Kewirausahaan, 6(1), 1-8. DOI: https://doi.org/10.26905/jmdk.v6i1.1985

Riana, I.G., Wiagustini, N.L.P., Dwijayanti, K.L., \& Rihayana, I.G. (2018). Managing WorkFamily Conflict and Work Stress through Job Satisfaction and Its Impact on Employee Performance. Jurnal Teknik Industri, 20(2), 127-134. DOI: https://doi.org/10.9744/jti.20.2.127-134

Krisnawati, S., \& Lestari, Y.T. (2018). Stres dan konflik kerja pengaruhnya terhadap kinerja karyawan. Jurnal Riset Manajemen dan Bisnis (JRMB), 3, 285 - 292. DOI: https://doi.org/10.36226/jrmb.v3iS1.146

Erwandari, E.P., \& Sari, A.P. (2010). Pengaruh konflik kerja dan stres terhadap kinerja karyawan pt pos indonesia (persero) bengkulu 38000. Management Insight, 13(2), 39-49. DOI: https://doi.org/10.33369/insight.13.2.39-49

Fatikhin, F., Hamid, D., \& Mukzam, M.D. (2017). Pengaruh konflik kerja dan stres terhadap kinerja karyawan (studi pada karyawan pt. bank rakyat indonesia (persero) cabang soekarno hatta malang). Jurnal Administrasi Bisnis, 47(1), 172-180. DOI: https://doi.org/10.36805/akuntansi.v1i1.43 
Sedarmayanti. (2011). Manajemen Sumber Daya Manusia, Reformasi Birokrasi dan Manajemen Pegawai Negeri Sipil. cetakan kelima. Bandung: PT Refika Aditama.

Newstrom, J., and K. Davis. (1993). Human Behavior at Work. Organization Behavior 8th Edition. Singapore: Mc. Graw-Hill. International.

Sarafino, E.P. (2006). Health Psychology : Biopsychosocial Interactions. Fifth Edition. USA: John Wiley \& Sons.

Luthans, F. (1998). Organizational Behavior. Eight Edition. New York: McGraw-Hill Co.

Andreas Lako. (2004). Kepemimpinan dan Kinerja Organisasi Isu Teori dan Solusi. Yogyakarta: Amara Books. 